\title{
Diabetic Rural Women's Attitudes toward Diabetes in Iran
}

\author{
Fariba Heidari and Maryam Baradaran Binazir* \\ Health Management and Safety Promotion Research Institute, Tabriz University of Medical Sciences, Iran
}

Submission: June 30, 2021; Published: July 19, 2021

*Corresponding author: Maryam Baradaran Binazir, Health Management and Safety Promotion Research Institute, Tabriz University of Medical Sciences, Iran

\begin{abstract}
For controlling chronic disease as diabetes, the attitude toward the disease is important. The aim of this study was to evaluate diabetic rural women's attitude toward their disease. This cross-sectional study was done on the women with diabetes referred to the health center in a village, East Azarbayjan, Iran, 2019. The Diabetes Attitudes Questionnaire (DAS) was applied to assess diabetic rural women's attitude. Totally 85patients participated in our study. The mean attitude score was76.27 \pm 6.81 . There was a positive correlation between the score of patients' attitudes and their educational level.
\end{abstract}

Keywords: Diabetes; Women; Attitudes

\section{Introduction}

The overall prevalence of diabetes mellitus was reported to be nearly $9 \%$ among people older than 18 years in 2018. Most of diabetic patients live in developing countries [1]. Poor controlled diabetes mellitus is a main origin of chronic complications containing cardiovascular disease, nephropathy and neuropathy [2]. It has serious effects on the patient's life and community. In addition, higher rates of diabetes cause a considerable burden on healthcare systems [3]. Frequency of diabetes in Iran is approximately seven million people, more than half of them (about four and a half million) are unfamiliar with their diabetes disease and do not get any care at all [4]. The importance of the appropriate attitude toward chronic diseases, containing diabetes, has been addressed in different studies, and nowadays, it has been identified as an important factor to face with such chronic diseases [5]. Because there is no research in East Azarbaijan province of Iran on the attitude of rural patients toward their diabetes disease, we decided to conduct a study to evaluate diabetic rural women's attitude toward their disease.

We performed a cross-sectional study. The convenient sampling method was done to select women with type 2 diabetes referred to Saeidabad's primary health center from Jun 2019 to December 2019. Saeidabad is a big village in East Azarbaijan, Iran. We used Diabetes Attitude Survey (DAS) questionnaire, a reliable and valid questionnaire to evaluate patient's attitudes toward diabetes $[6,7]$. The questionnaire had two sections: the first section was contained demographic characteristics of rural women (Table 1), and the second section was contained 30 questions in 5-point Likert scale (strongly agree, agree, neutral, disagree, and strongly disagree that graded 5 to 1 respectively. So, the maximum and minimum obtainable scores were 150 and 30respectively. Then the valuation criteria were determined as follows: valuation of 101-150: appropriate, valuation of 51-100: moderately appropriate, valuation of $\leq 50$ : unappropriated). The participants completed the questionnaire after signing the written informed consent. This study was approved by the Ethics Committee of Tabriz University of Medical Sciences with an ethical approval number of IR.TBZMED.REC.1398.068.

Totally, 85 rural women entered the study. The mean age (SD) of participants was $50.31(3.2)$ years. The most of participants had Family history of diabetes (83.5\%). The mean attitude score was76.27 \pm 6.81 . There was a positive correlation between the scores of patients' attitudes and their educational level $(r=0.221$, $\mathrm{p}=0.001)$.

\section{Conclusion}

The diabetic rural women have moderately acceptable attitude toward their disease, proper interventions are needed to make better their attitudes. 


\section{Current Research in Diabetes \& Obesity Journal}

Table1: Demographic characteristics of diabetic rural women $(n=85)$.

\begin{tabular}{|c|c|}
\hline Variables & N (\%) \\
\hline \multicolumn{2}{|l|}{ Age } \\
\hline $30 \geq$ & $2(2.3)$ \\
\hline $31-40$ & $15(17.6)$ \\
\hline $41-50$ & $25(29.4)$ \\
\hline $51-60$ & $32(37.6)$ \\
\hline $61 \leq$ & $11(12.9)$ \\
\hline \multicolumn{2}{|c|}{ Marital status } \\
\hline Single & $5(5.8)$ \\
\hline Married & $80(94.2)$ \\
\hline \multicolumn{2}{|c|}{ Educational level } \\
\hline Illiterate & $2(2.3)$ \\
\hline primary school & $26(30.5)$ \\
\hline High school & $54(63.5)$ \\
\hline academic & $3(3.5)$ \\
\hline \multicolumn{2}{|c|}{ Duration of diabetes (Years) } \\
\hline $5 \geq$ & $35(41.1)$ \\
\hline 10-Jun & $37(43.5)$ \\
\hline $11 \leq$ & 13(15.2) \\
\hline Family history of diabetes (Yes) & $71(83.5)$ \\
\hline
\end{tabular}

CC This work is licensed under Creative
Commons Attribution 4.0 Licen

\section{Acknowledgement}

We appreciate all rural women participated in this study.

\section{References}

1. Animaw W, Seyoum Y (2017) Increasing prevalence of diabetes mellitus in a developing country and its related factors. PloS one 12(11): e0187670.

2. Flor LS, Campos MR (2017) The prevalence of diabetes mellitus and its associated factors in the Brazilian adult population: evidence from a population-based survey. Revista Brasileira de epidemiologia 20(1): $16-29$

3. Endris T, Worede A, Asmelash D (2019) Prevalence of diabetes mellitus, prediabetes and its associated factors in Dessie Town, Northeast Ethiopia: a community-based study. Diabetes, metabolic syndrome and obesity: targets and therapy 12: 2799-2809.

4. Rashedi V, Asadi LM, Delbari A, Fadayevatan R, Borhaninejad V, et al. (2017) Prevalence of diabetes type 2 in older adults: Findings from a large population-based survey in Tehran, Iran (Urban HEART-2). Diabetes \& Metabolic Syndrome: Clinical Research \& Reviews 11: S347-S350.

5. Alsous M, Abdel JM, Odeh M, Al Kurdi R, Alnan M (2019) Public knowledge, attitudes and practices toward diabetes mellitus: A crosssectional study from Jordan. PloS one 14(3): e0214479.

6. Anderson RM, Fitzgerald JT, Funnell MM, Grupen LD (1998) The Third Version of the Diabetes Attitude Scale (DAS-3). Diabetes Care 21(9): 1403-1407.

7. Mahjouri MY, Arzaghi SM, Qorbani M, Nasli EE, Larijani B (2011) Evaluation of psychometric properties of the third version of the Iranian Diabetes Attitude Scale (IR-DAS-3). Journal of Diabetes and Metabolic Disorders 10: 8.

Your next submission with Juniper Publishers
will reach you the below assets
- Quality Editorial service
- Swift Peer Review
- Reprints availability
- E-prints Service
- Manuscript Podcast for convenient understanding
- Global attainment for your research
- Manuscript accessibility in different formats
( Pdf, E-pub, Full Text, Audio)
- Unceasing customer service
Track the below URL for one-step submission
https://juniperpublishers.com/online-submission.php

